\title{
Praanggapan Pada Tuturan Neneng Garut: Kajian Pragmatik dalam Stand Up Comedy Academy (SUCA 3)
}

\author{
Prapti Wigati Purwaningrum \\ Fakultas Komunikasi dan Bahasa \\ Program Studi Bahasa Inggris, \\ Universitas Bina Sarana Informatika Jakarta \\ Prapti.pwp@bsi.ac.id
}

\author{
Cara Sitasi: \\ Purwaningrum, P. W. (2019). Praanggapan Pada Tuturan Neneng Garut: Kajian Pragmatik dalam Stand Up \\ Comedy Academy (SUCA 3). Wanastra, 11(1), 07-14.
}

\begin{abstract}
In stand up comedy show komika often uses presuposition to convey the message. The audiences must have knowledge background in understanding it. The aim of this study is to examine the presuppositions of Neneng Garut's utterances through pragmatic studies. This is a qualitative study with content analysis method because this study prioritizes the content approach of the speech. The data source of this research is Neneng Garut's utterances which contains presuppositions and implicature in Stand Up Comedy Academy (SUCA 3). Data provision of this analysis is done by using simak method that is applied through note-taking techniques. The results of this study indicate that Neneng Garut would like to convey that at present more and more cases of corruption have occurred and are increasingly difficult to stop it. This is said through the puncline and if we ask Indonesia for corruption free, it is very difficult, especially when we ask Radit to marry, it is more difficult. In addition, in this study also found some presuppositions in her utterances such as, presuppositions about the difficulty and limited transportation in remote region of Garut, the lack of entertainment, trust in mysticism that is still very thick, and a way of thinking in society. In addition, through pragmatic, presupposition, and understanding the implicit meanings, the writer hopes that the results of this paper will be able to contribute ideas to the reading community about the importance of hearing and understanding the speech of the partners in a society that has lately faded.
\end{abstract}

Keywords: Presupposition,Implicatures, Stand Up Comedy Academy Indosiar 3

\section{PENDAHULUAN}

Beberapa tahun terakhir ini Stand Up Comedy menjadi salah satu hiburan yang cukup dinantikan oleh penonton televisi. Seni komedi ini disuguhkan secara individu one man show dengan materi-materi yang cukup menggelitik tidak jarang berisi kritikan dan sindiran tentang sesuatu hal. Cara berhumor dengan stand up comedy ini sangat berbeda dengan jenis humor atau lawakan lain yang sudah pernah ada. Pada Stand up comedy penonton harus memiliki kesamaan pengetahuan tentang apa yang sedang dibawakan oleh para komika, karena komedi ini dibawakan hanya dengan menggunakan bahasa dan cara bercerita serta act out yang mendukung agar pesan dapat sampai dan diterima oleh penonton.

Dalam beberapa penampilannya terkadang para komika tidak secara tersirat menyampaikan pesan dalam tiap lawakannya. Mereka lebih sering menggiring penonton untuk mencerna dan berfikir kritis tentang pesan dalam setiap materi yang mereka bawakan, lalu munculah praanggapan dari penonton yang biasanya segera dipatahkan melalui punchline oleh komika.
Dalam stand up komedi sering dikenal dengan istilah punchline, dalam tulisannya (Widya, 2015) menyebutkan bahwa puncline adalah bagian lucu dari jokes. Bagian inilah yang mematahkan pranggapan yang terbangun dipikiran penonton, yang menimbulkan kelucuan. Untuk memahami sebuah pesan yang tersirat dalam sebuh tuturan diperlukan sebuah kajian pragmatik.

Menurut Gazdar dalam (Nadar, 2009) Pragmatik adalah kajian antara lain mengenai deiksis, implikatur, presuposisi, tindak tutur, dan aspekaspek struktur wacana. Dalam mengkaji makna tidak semata-mata memahami makna pesan yang tersurat melainkan makna tersirat yang dapat dipahami melalui sebuah konteks.

Konteks akan selalu ada dalam sebuah tuturan. Menurut (Leech, 1993) konteks merupakan latar belakang pemahaman yang dimiliki oleh penutur maupun lawan tutur sehingga lawan tutur dapat membuat interpretasi mengenai apa yang dimaksud oleh penutur pada waktu membuat tuturan tertentu. Selain konteks Praanggapan menjadi hal yang sangat penting untuk memahami sebuah pesan dalam tuturan yang dituturkan oleh para komika. 
Menurut (Wijana, 1996) menyatakan bahwa sebuah kalimat dinyatakan mempresuposisikan kalimat yang lain jika ketidakbenaran kalimat yang kedua (kalimat yang dipresuposisikan) mengakibatkan kalimat pertama (kalimat yang mempresuposisikan) tidak dapat dikatakan benar atau salah. Praanggapan merupakan apa yang digunakan penutur sebagai dasar bersama bagi para peserta percakapan. Melalui sebuah praanggapan petutur akan dapat memberikan asumsi terhadap apa yang penutur tuturkan dalam konteks tertentu.

Menurut (Yule, 1996), praanggapan merupakan apa yang digunakan penutur sebaga dasar bersama bagi para peserta percakapan. Pendapat lain juga diungkapkan oleh (Rahardi, 2005) sebuah tuturan dapat dikatakan mempraanggapkan tuturan yang lain apabila ketidakbenara tuturan yang diproposisikan mengakibatkan ketidakbenaran atau kebenaran. Praanggapan merupakan suatu tuturan yang mengandung makna kebenaran atau ketidakbenaran sesuai dengan tuturannya.

Berawal tayang di Metro TV lalu Kompas TV dan 4 tahun terkhir ini juga tayang di Indosiar dengan nama program Stand Up Comedy Academy (SUCA). Suca 1 dijuarai oleh Cemen dari Cikarang, Suca 2 dijuarai oleh Aci Resti Jakarta, Bintang Emon dari Jakarta sebagai juara ketiga, dan yang baru-baru ini muncul sebagai juara SUCA 4 adalah Oki dari Palu.

Namun dari sekian banyak juara ada satu peserta yang cukup menarik perhatian penulis, dia dikenal dengan keluguan dan kejujurannya. Bahkan Pandji salah satu juri di SUCA 4 berpendapat bahwa kejujurannya terlalu "brutal", dia adalah Neneng. Peserta ini masih muda, siswa SMEA dan yang menjadi ciri khasnya adalah logat Sunda. Dia berasal dari Garut Jawa Barat. Meskipun Neneng hanya berada diperingkat 4 , namun hampir setiap penampilannya mampu mampu memancing tawa penonton dan juga para juri.

Di setiap penampilannya Neneng selalu menyelipkan materi yang berkaitan dengan kampungnya di Garut. Hal inilah yang membawa penonton ikut serta mengembalikan pengetahuan serta membayangkan tentang keadaan di kampung yang masih jauh dari jangkauan teknologi dan hiburan layaknya di kota. Neneng membawakan materi selalu menggiring asumsi penonton bahwa di kampungnya yaitu Garut masih sangat jauh dari teknologi, pendidikan, transportasi, kepercayaan, dan kehidupan sosial masyarakatnya. Semua itu dituturkan dengan kentalnya logat sunda dan kepolosan serta kejujuran yang brutal. Dalam tulisan ini penulis hanya mefokuskan pada maksud dari praanggapan dalam tuturan Neneng pada stand up comedy academy (SUCA 5)

\section{METODOLOGI PENELITIAN}

\section{Pendekatan penelitian}

Penelitian ini menggunakan pendekatan kualitatif. Analisis isi merupakan metode yang digunakan dalam penelitian ini karena penelitian ini lebih mengutamakan pendekatan konten dari Neneng Garut dalam Stand Up Comedy Indosiar season 3 (SUCA 3) Penulis memilih acara tersebut karena merupakan jenis komedi terbaru, humornya mudah dipahami, dan mengajak penonton untuk berfikir untuk dapat memahami setiap materi khususnya yang dibawakan oleh Neneng dari Garut, dan yang terpenting banyak terdapat tuturan yang mengandung implikatur dan praaggapan yang dipatahkan melalui punchline dan menimbulkan tawa. Data penelitan berupa penggalan tuturan dari komika yang bernama Neneng berasal dari Garut SUCA 3.

\section{Proses penyediaan data}

Menurut Sudaryanto (Sudaryanto, 2015) ada dua metode penyediaan data yaitu metode simak dan cakap. Pada penelitian ini penulis menggunakan metode simak untuk proses penyediaan data. Metode ini dipilih karena objek yang diteliti berupa teks yang berupa penggalan tuturan. Untuk menerapkan metode tersebut penulis menggunakan teknik catat untuk mencatat tuturan dalam tuturan yang mengandung implikatur dan praanggapan.

Sumber data penulisan ini adalah tuturan dari komika bernama Neneng yang berasal dari Garut finalis Stand Up Comedy Academy (SUCA 3) yang ditayangkan di Indosiar. Penyediaan data dilakukan dengan menonton penampilan Neneng Garut, mengidentifikasi tuturan yang mengandung implikatur dan praanggapan lalu menelaah maksud yang dihadirkan melalui raanggapan.

Telah banyak pembahasan tentang praanggapan salah satunya dari (Andryanto, S.F., Andayani, Rohmadi, 2014) yang membahas tentang praanggapan yang ada di tayangan SKETSA denan simpulan bahwa penting untuk memahami praanggapan agar tidak terjadi kesalahpahaman antara penutur dan petutur.

Pembahasan praanggapan lainnya disampaikan oleh (Retnosari, 2014) yang menyimpulkan bahwa adanya kemampuan lebih untuk mampu memahami praanggapan maka dapat meningkatkan kualitas komunikasi.

Pendapat lain dari (Liang \& Liu, 2016) tentang pentingnya praanggapan dalam tuturan dapat memperkuat serta membuat pesan yang ingin disampaikan oleh penutur pada petutur menjadi lebih jelas. Dalam tulisannya Liang dan Liu jika 
praanggapan muncul dalam sebuah pidato akan sangat membantu tejadinya interaksi yang baik antara penutur dan audience dalam memahami pesan dari pidato tersebut.

\section{HASIL DAN PEMBAHASAN}

Menurut Grice dalam (Yule, 1996) menyatakan bahwa implikatur merupakan makna lain dari sebuah tuturan atau dapat disebut efek dari sebuah tuturan. Berdasarka definisi tersebut dapat disimpulkan bahwa implikatur merupakan makna lain yang tersirat dalam sebuah tuturan yang ingin disampaikan dalam sebuah tuturan. Terkadang implikatur muncul untuk menyampaikan sebuah perintah, kritik bahkan untuk menyindir terhadap suatu hal. Berikut beberapa implikatur yang muncul dalam tuturan Neneng Garut dalam Stand $U p$ Comedy SUCA 3 di Indosiar.

\section{A. Implikatur dari tuturan Neneng Garut di SUCA 3}

Tuturan bermaksud menyindir tentang maraknya korupsi di Indonesia saat.

Data $6:(0: 30-0: 38)$ dan (1:16-1:30/SUCA 3)

Neneng teh pengangguran, Jadi pengangguran di Garut mah engga enak, sering dibanding-bandingin, masih mending dibandingin sama tetangga, Neneng sama domba (0:30-0:38).

Tapi sebenarnya teh Neneng pengangguran sebenarnya bukan tanpa alasan, Neneng pengangguran teh gara-gara Neneng belum punya KTP, jadi jangan salahkan Neneng atuh kalo Neneng pengangguran, salahin mah orang yang makan dana uang KTP (1:16-1:30).

Dalam penggalan tuturan di atas, Neneng tidak ingin hanya sekedar melemparkan humor tetapi ada sebuah pesan yang ingin dia sampaikan yang mungkin saja hal itu merupakan keresahan dia atau bahkan warga kampung di pelosok Garut. Berawal dari tuturan Neneng tentang dia yang pengangguran, dengan keadaanya tersebut tidak jarang disindir bahkan oleh ayahnya sering disamakan dengan domba peliharaan yang mampu menghasilkan uang, sementara Neneng tidak ada yang dapat dia lakukan.

Neneng bertutur mencoba memberikan pernyataan atas apa yang dia rasakan tentang yang dia alami sebagai pelanggaran. Dia tdak ingin selalu dipertanyakan mengapa sampai sekarang dia masih menganggur, Neneng bertutur jadi jangan salahkan Neneng atuh kalo Neneng pengangguran, salahin mah orang yang makan dana uang KTP. Dalam tuturan tersebut tidak semata-mata Neneng berututur tetapi ada sebuah pesan yang tersirat bahwa dia ingin menyuarakan bahwa salah satu alasan dia belum memiliki KTP adalah adanya kendala pendistribusian ke desanya yang disebabkan oleh penyalahgunaan dana KTP yang hingga saat ini belum jelas penangannya.

Melalui tuturan tersebut antara Neneng dan penonton memiliki pengetahuan yang sama tentang merebaknya kasus korupsi penyelewengan dana KTP sehingga berimbas pada tertundanya pendistribusian dana KTP ke pelosok-pelosok desa termasuk desa Neneng. Meskipn tuturan tersebut bersifat menyindir, namun mampu memancing penonton untuk tertawa.

\section{Data $13:(4: 14-4: 50 /$ SUCA 3$)$}

Kalo orang-orang di kampung Neneng liat kapal udara mereka the teriak kapal minta uang. Maklum atuh yah orng kampung masih minta uang, kalo minta Indonesia bebas korupsi mah sulit. Apalagi kalo minta bang Radit untuk nikah, itu lebih sulit.... Bahkan itu teh mustahil, kalaupun bang Radit dapat jodoh itu teh itungannya mukjizat (4:14-4:50)

Pada data 13 ini Neneng kembali tidak sekedar bertutur tetapi juga ingin menyampaikan sesuatu yang masih menjadi keresahan dia. Diawali dengan penggiringan opini penonton tentang keadaan di kampungnya yang digambarakan dengan begitu polosnya Kalo orang-orang di kampung Neneng liat kapal udara mereka teh teriak kapal minta uang. Maklum atuh yah orang kampung masih minta uang, kalo minta Indonesia bebas korupsi mah sulit. Ada pesan dibalik tuturan Neneng bahwa saat ini korusi sudah merajalela bahkan sudah mendarah daging, hingga untuk menghapusnya menjadi sesuatu hal yang sulit bahkan mustahil untuk dilakukan di Indonesia.

Melalui tuturan tersebut ada kesamaan pengetahuan antara Neneng dan penonton dalam hal korupsi yang sudah merebak di Indonesia dan sangat sulit untuk dihapus. Dengan demikian sindiran yang disampaikan Nenneg tetap mampu memancing tawa ditambah dituturkan dengan keluguan dan kepolosan Neneng, selain itu implikatur tesebut juga dipatahkan oleh Neneng melalui punchline Apalagi kalo minta bang Radit untuk nikah, itu lebih sulit.... Bahkan itu teh mustahil, kalaupun bang Radit dapat jodoh itu teh itungannya mukjizat. Dua hal antara menghentikan korupsi di Indonesia dan meminta bang Radit menikah merupakan dua hal yang sangat berlainan tetapi disinilah muncul lawakan sekaligus pesan yang justru keduanya dapat diterima oleh penonton.

\section{B. Praanggapan dalam tuturan Neneng Garut SUCA 3}




\section{Praanggapan tentang transportasi di daerah pelosok Garut.}

Melalui tuturannya Neneng Garut mencoba memunculkan praanggapan tentang berbagai transportasi murah yang masih jauh dari kesan modern di pelosok Garut. Transportasi di pelosok Garut masih relatif murah, jarang atau jumlahnya sangat sedikit, sehingga saat masyarakat ingin menggunaknnya harus antre atau rela berdesakdesakan. Transportasi yang ada di pelosok Garut seperti angkot, ojek, kol bunting, dan delman. Dari jenis transportasi yang telah disebutkan oleh Neneng hanya ojek yang tergolong mahal. Dari tturan tersebut penonton akan terdorong untuk memiliki praanggapan tentang gambaran tentang desa Neneng di pelosok garut. Hal ini dapat dilihat dari beberapa tuturan berikut:

\section{Data 1, 2, dan 3}

(1)saya Neneng dari Garut, akang teh di Garut mah angkot susah, ojek mahal. (2) Ojek online modal harus ada kuota, di kampung Neneng mah mahal kalo mau murah harus pacaran ama anak kepala desa.

Dari data (1) dan (2) Neneng menggunakan alat transpostasi yang ada di desanya untuk menggiring praanggapan penonton tentang desanya yang masih memiliki alat transportasi langka, murah dan sederhana. Dari tuturan angkot susah, ojek mahal mendorong opini penonton untuk membayangkan dan sedikit merasakan masih adanya keterbatasan dalam transportasi. Tapi praanggapan tersebut dimainkan melalui punchline Ojek online modal harus ada kuota, di kampung Neneng mah mahal kalo mau murah harus pacaran ama anak kepala desa. Hal ini dapat diartikan bahwa sebuah kelucuan dapat dibangun oleh Neneng melalui puncline atau memainkan presuposisi yang sudah ada.

(3) tapi ada solusinya naik angkot, Cuma angkotnya selalu penuh. Ada tukang ayam, tukang ikan makanya warga kampung Neneng lebih pilih naik delman kayak delman pribadi bisa selonjoran, tiduran, bayar bulanan.

Hal yang serupa juga terjadi pada data (3) bahwa Neneng mencoba kembali membangun praanggapan pada penonton dengan memanfaatkan alat transportasi yang murah yaitu delman melalui tuturan makanya warga kampung Neneng lebih pilih naik delman. Penonton pada umumnya telah memiliki pengetahuan tentang delman yaitu transportasi tradisional yang dikendalikan oleh tenaga kuda. Maka Neneng berhasil memberikan praanggapan tentang keterbatasan, kesederhanaan, dan harga sangat murah dengan hanya 2 ribu rupiah. Neneng kembali memainkan presuposisi tersebut melalui tuturan kayak delman pribadi bisa selonjoran, tiduran, bayar bulanan. Penonton yang awalnya sedikit tersentuh dengan praanggapan tentang desa di pelosok Garut sesaat tertawa, hal ini menjadi suatu hal yang unik dan jauh dari kesan memprihatinkan.

\section{Praanggapan keadaan wilayah di Pelosok Garut}

Penonton telah memiliki pengetahuan tentang Garut sebuah kota di Jawa Barat, teapi dalam tuturannya Neneng selalu membangun praanggapan penonton bahwa dia tinggal di pelosok Garut yang jauh dari mana-mana, transpostasi terbatas, sulit, dan mahal selain itu kondisi geografisnyapun digambarkan dengan jalanan rusak, banyak lobang, dan banyak sungai. Berikut praanggapan yang dihadirkan oleh Neneng tentang keadaan geografis di kampungnya:

Data 5 (0:01-0:16)

saya teh Neneng dari Garut, rumah Neneng di Garut the dipelosok banget. Saking pelosoknya nih sinyal itu ga ada, sinyal hp juga ga ada, dan sinyal-sinyal bang Radit bakal nikah juga ga akan pernah ada.

Dari penggalan tuturan di atas Neneng mencoba mengaitkan kondisi sekarang yang serba canggih, akses internet dengan mudah dan murah, namun tidak demikian yang terjadi di kampung Neneng di pelosok Garut. Praanggapan yang dibangun adalah di kampung Neneng sangat terpencil hingga internetpun tidak dapat menjangkau daerah disana. Praanggapan tersebut dibangun untuk mengarahkan penonton berfikir, membayangkan bahkan berempati tentang keadaan yang sangat bertolak belakang dengan kota-kota besar yang begitu mudah mengakses internet. Namun praanggapan tersebut dinyatakan melalui puncline Dan sinyal-sinyal bang Radit mau nikah juga ga ada. Hal ini menunjukan bahwa dengan menggunakan puncline pada praanggapan yang sudah dibangun akan memberikan kelucuan dan mengundang tawa penonton karena penonton juga mengetahui bahwa bang Radit saat itupun masih belum menikah.

\section{Data $11(2: 50-3: 25 /$ SUCA 3)}

Dasana delman pake speaker, lagunya-lagu dugem. Udah gitu bayarnya teh murah karena setara dengan tingkat keselamatannya Cuma 2 ribu, ngelewatin jalanan yang rusak, trus pinggirnya sungai, udah banyak korbannya. Sampai ada papan informasinya hati-hati banyak delman masuk sungai. Tiga orang luka ringan, 4 kusir basah kuyup, dua kuda ngambang.

Dalam tuturan ngelewatin jalanan yang rusak, trus pinggirnya sungai, udah banyak korbannya, merupakan praanggapan yang dibangun Neneng 
tentang keadaan jalan di desanya. Hal ini menggiring opini penonton bahwa daerahnya jauh dari kesan modern, nyaman yang ada hanya rasa khawatir saat melintasi jalan tersebut, tidak ada jaminan keselamatan hanya peringatan tentang apa saja yang sudah terjadi di jalan tersebut, hal ini terlihat dalam tuturan Sampai ada papan informasinya hati-hati banyak delman masuk sungai. Praanggapan tersebut dimainkan melalui punchline Tiga orang luka ringan, 4 kusir basah kuyup, dua kuda ngambang yang mampu memancing tawa penonton.

\section{Data 9 (0:42-0:50) dan (3:10-3:41/SUCA 3)}

Di kampung Neneng mah ga ada mall, jadi tempat nongkrong paling murah mah teh ya di indomerit. Rumah Neneng jauh kemana-mana, jadi jauh ke indomerit, teteh bisa kapan aja ke indomerit neng mah satu bulan sekali, jadi di kampung Neneng teh ke indomerit tuh jauh itungannya udah kayak merantau. Jadi kalo neneg mau berangkat ke indomerit sun tangan sama emak, abah minta keselamatan di jalan supaya ga dicegat begal. Bagi orang-orang di kampung Neneng pergi ke indomaret wajib bagi yang mampu.

Selain pasar malam, tayangan film bioskop di TV, ternyata indomerit (tuturan Neneng) menjadi salah satu tempat hiburan atau nongkrong di desa Neneng. Dalam tuturannya Neneng memanfaatkan keadaan desanya yang saat itu tidak ada mall, yang ada hanya indomerit itupun jaraknya jauh dari kampung Neneng Rumah Neneng jauh kemana-mana, jadi jauh ke indomerit, teteh bisa kapan aja ke indomerit neng mah satu bulan sekali, ke indomerit udah kayak merantau. Tuturan tersebut diperjelas lagi dengan ke indomerit udah kayak merantau Jadi kalo neneg mau berangkat ke indomerit sun tangan sama emak, abah minta keselamatan di jalan supaya ga dicegat begal praanggapan yang dibangun oleh Neneng di depan penonton membuat penonton memahami betapa terpencilnya daerah Neneng dan melewati daerah sepi yang rawan kejahatan untuk dapat sampai ke indomerit, jarak tempuh yang jauh membuat desa Neneng kurang dapat menikmati berbagai hiburan.

Namun praanggapan tersebut kembali dimainkan nenneg melalui patahan atau punchline Jadi bagi orang-orang di kampung Neneng pergi ke indomaret wajib bagi yang mampu, yang mampu memancing tawa penonton, karena penonton memiliki pengetahuan tentang tuturan wajib bagi yang mampu biasanya untuk pengetahuan tentang melaksanakan ibadah haji, ini dikaitkan dengan pergi ke indomerit (jd bisa saja berkunjung ke indomerit hanya sebuah impian bagi orang-orang yang benar-benar belum memiliki uang lebih).

\section{Praanggapan mengenai hiburan di Pelosok Garut}

Di jaman modern seperti sekarang ini, hiburan telah menjadi sebuah kebutuhan hidup harus dipenuhi. Berbagai macam hiburan dapat ditemui khususnya di kota besar. Namun hal ini sangat bertolak belakang di kampung Neneng di pelosok Garut yang masih sangat terbatas dan sulit untuk mendapatkan hiburan.

\section{Data 4 (0:15-0:45/SUCA 3)}

Kadang Neneng teh suka iri sama akang teteh rumah di kota. Rumah Neng di kampung jarang ketemu hiburan, hiburan 3 bulan sekali itupun pasar malem, wahana Cuma 2 komedi puter sama tukang arumanis. Jadi kalo misal komedi putarnya penuh, ya neneng naik mesin arumanis sama-sama muter, sama-sama pusing.

Pada data 4 diatas, Neneng dengan kepolosannya berusaha membangun praanggapan tentang hiburan di kampung Neneng yang masih jauh dari kesan modern, namun demikian tetap terkesan seru. Rumah Neng di kampung jarang ketemu hiburan, hiburan 3 bulan sekali itupun pasar malem, wahana Cuma 2 komedi puter sama tukang arumanis. Dari tuturan tersebut penuntun pemahaman penonton tentang jenis hiburan di desa neneng, sebuah pasar malam dengan komedi putar dan tukang arumanis menjadi suatu hiburan di masyarakat. Hiburan ini sangat dinantikan karena hanya dapat mereka nikmati tiga bulan sekali itupun belum tentu dapat naik komedi putar, karena banyaknya warga yang ingin naik jadi terkadang neneng tidak kebagian.

Praanggapan tersebut menggiring penonton bahwa desa nenneg masih dalam keterbatasan termasuk dalam memperoleh hiburan. Neneng mengajak penonton untuk sebentar membayangkan dan berempati tentang daerah denagn minimnya hiburan, namun praanggapan tersebut dialihkan melalui punchline Jadi kalo misal komedi putarnya penuh, ya neneng naik mesin arumanis sama-sama muter, sama-sama pusing. Memancing tawa penonton, karena penonton telah memiliki pengetahuan tentang seperti apa dan seberapa besar mesin arummanis untuk dapat dinaiki oleh neneng.

\section{Praanggapan mengenai kepercayaan di Pelosok Garut}

Di era yang sudah dipenuhi dengan kecanggihan teknologi ternyata di pelosok Garut masih banyak sekali yang percaya pada hal yang ghoib. Neneng kembali menceritakan tentang hal mistis yang masih ada. Barikut tuturan neneng yang mendorong 
praanggapan penonton tentang hal mistis yang masih sering dilakukan warga disana.

Data 7: $(2: 00-2: 30)$

Rumah Neneng kan di pelosok ya, jadi kuat sama hal-hal yang mistis. Di kampung Neneng dukun lebih laku daripada dokter. Abah Neneng pengen punya banyak uang pergi ke dokter, ade Neneng pengen punya pacar pergi ke dukun, sampai dokternya pengen punya banyak pasien pergi ke dukun.

Neneng memiliki praanggapan bahwa masyarakat di desanya tepatnya di pelosok Garut masih erat dengan hal mistis terlihat dalam tuturan Di kampung Neneng dukun lebih laku daripada dokter. Abah Neneng pengen punya banyak uang pergi ke dokter, ade Neneng pengen punya pacar pergi ke dukun. Tuturan tersebut mengantar kanpenonton tentang hal-hal mistis yang mungkin saja masih berlaku di pelosok-pelosok seperti yang Neneng ceritakan, sehingga penonton memahami apa yang dipraanggapkan oleh Neneng.

Praanggapan tersebut dimainkan melalui punchline yang menyusul dalam tuturan terasebut yaitu sampai dokternya pengen punya banyak pasien pergi ke dukun. Tuturan ini menjadi lemparan humor yang mampu menarik penonton untuk tertawa karena pengetahuan selama ini bahwa seorang dokter sudah paham teknologi, dan segala sesuatu diukur dengan teori atau ilmu yang masuk kedalam logika, tetapi ternyata Neneng bertutur sampai dokternya Data 8 (3:28-3:53/SUCA)

Di Garut mah ga ada bioskop, jadi sekalinya film bioskop tayang di TV Neneng sama keluarga teh antusias banget gitu. Sebisa mungkin suasana di rumah bisa main sama kayak suasana di bioskop, lampu teh Neneng matiin, bangku Neneng jejerin, orang pacaran Neneng masukin.

Berdasarkan data 8 Neneng menuturkan bahwa di pelosok Garut tepatnya desa Neneng tidak ada bioskop, hal ini sangat berlawanan dengan keadaan sekarang saat orang dengan begitu mudahnya menikmati tontonan di bioskop. Hal ini dituturkan melalui Di Garut mah ga ada bioskop, jadi sekalinya film bioskop tayang di TV Neneng sama keluarga teh antusias banget gitu. Tuturan tersebut mengarahkan penonton bahwa di pelosok Garut masih sangat jauh tertinggal dalam hal hiburan, hingga digambarkan dengan betapa gembiranya jika salah satu film bioskop tayang di TV.

Praanggapan tersebut dimainkan melalui punchline Sebisa mungkin suasana di rumah bisa main sama kayak suasana di bioskop, lampu teh Neneng matiin, bangku Neneng jejerin, orang pacaran Neneng masukin. Hal ini memancing tawa penonton sekaligus ikut membayangkan sebuah rumah dengan TV yang sedang menayangkan film bioskop lalu rumah ditata seperti bioskop, bapak ibunya sebagai penjual popcorn alangkah lucu dan konyol keluarga tersebut, sekaligus mengingatkan semuanya bahwa masih ada di pelosok desa yang masih sangat sulit untuk mendapatkan hiburan.

\section{Data 10 (2:45-2:55/SUCA 3)}

Neneng dateng teh mall nya gede banget ada kali 3 kelurahan disatuin. Sesampainya ditempat karaoke ternyata harganya teh 75 ribu 1 jam mahal banget. Di kampung neneng mah 70 ribu bisa buat sewa dangdut dorong, 75 ribu plus biduan.

Praanggapan yang dibawakan Neneng menawarkan sebuah pengetahuan bahwa di era yang sudah modern sekarang ini, ternyata dangdut dorong masih merupakan salah satu bentuk hiburan yang dapat dinikmati oleh warga pelosok desa Garut. Hal ini dikaitkan dengan pengalaman dia saat berkunjung ke mall melalui tuturan Sesampainya ditempat karaoke ternyata harganya teh 75 ribu 1 jam mahal banget. Di kampung neneng mah 70 ribu bisa buat sewa dangdut dorong. Dengan biaya tersebut praanggapan yang muncul bahwa Neneng dan bahkan mungkin warga lainnya akan lebih memilih untuk tetap di kampung untuk menikmati hiburan meskipun hanya dangdut dorong, daripada dengan 70 ribu hanya digunakan dalam satu jam, di ruangan gelap dan tidak jelas baca liriknya.

Praanggapan tersebut mengarahkan penonton bahwa di pelosok Garut dangdut dorong masih ada hingga kini masih menjadi bentuk hiburan masyarakat disana yang dapat dinikmati dengan harga murah. Lalu praanggapan tersebut dimainkan oleh Neneng dengan puncline 75 ribu plus biduan memancing tawa penonton dan menjadi sebuah hal yang menggelitik karena dengan harga terjangkau mereka yang dipelosok desa Garut dapat memiliki hiburan.

pengen punya banyak pasien pergi ke dukun merupakan dua hal yang bertolak belakang, tapi memang itu yang terjadi tawa penonton pecah.

\section{Praanggapan kehidupan masyarakat di Pelosok Garut}

Menurut tuturan Nenneg dalam materi stand up bahwa khususnya anak-anak cewe sudah ditekan oleh orang tuanya untuk segera memiliki pacar, karena dengan memiliki pacar para orang tua akan merasa memiliki kebanggan tersendiri terhadap anaknya.

Data $12(2: 30-2: 48)$ 
Anak-anak lain mah yah dilarang pacaran sama orang tuanya, neneng mah diteken, karena cewecewe di kampung neneng SMP udah nikah, udah janda, malah udah bisa ngrebut suami orang. Itu SMP lho Neneng Yang SMA belum bisa apa-apa, boro-boro ngrebut suami orang pacaran aja Neneng mah belum pernah, tapi sekalinya pacaran ngrebut suami orang.

Sebelumnya penonton telah memiliki pengetahuan baersama bahwa biasanya di pelosok-pelosok cenderung para orang tua menyuruh anaknya khususnya cewe untuk segera memiliki pacar lalu menikah, meskipun hal tersebut tidak selurunya. Hal ini didukung oleh praanggapan Neneng yang disampaikan melalui tuturan Anak-anak lain mah yah dilarang pacaran sama orang tuanya, Neneng mah diteken, karena cewe-cewe di kampung neneng SMP udah nikah, udah janda, malah udah bisa ngrebut suami orang. Data 12 ini membangkitkan skema tentang pemikiran sebagian masyarakat disana yaitu anak cewe khususnya harus nikah diuasia muda karena jika telat dari teman-teman seusianya akan dianggap sebagai perawan tua.

Praanggapan yang telah dituturkan Neneng tentang ana-anak cewe seusianya yang harus cepat punya pacar dimainkan kembali oleh Neneng dengan punchline Itu SMP lho Neneng Yang SMA belum bisa apa-apa, boro-boro ngrebut suami orang pacaran aja Neneng mah belum pernah, tapi sekalinya pacaran ngrebut suami orang. Hal ini seketika memancing tawa penonton karena pengetahuan yang telah dibangun sebelumnya bahwa Neneng resah karena terus didesak oleh orang tuanya untuk segera punya pacar, lalu dipatahkan dengan sekalinya pacaran ngrebut suami orang. Hal ini bisa diterima oleh penonton sebagian dari kepolosan neneng.

\section{KESIMPULAN}

Praanggapan yang dibangun oleh Neneng seorang peserta SUCA 3 berasal dari pelosok Garut dengan logat sunda yang kental mampu membangkitkan tentang skema pemikiran sebagian masyarakat di pelosok Garut. Dengan adanya kesamaan pengetahuan antara penonton dan materi yang Neneng bawakan, maka pesan yang tersirat dalam setiap tuturan neneng dapat diterima dan dipahami oleh penonton. Selain itu dengan adanya beberapa praanggapan yang dihadirkan oleh Neneng Garut lalu dimainkan melalui punchline dapat menghadirkan humor, memancing tawa penonton.

Berikut beberapa pesan tersirat yang disampaikan melalui tuturan Nenneg dalam SUCA 3 yaitu Neneng ingin menyampaikan bahwa saat ini semakin banyak kasus korupsi yang terjadi dan semakin sulit untuk diberantas dan dihentikan. Hal ini dituturkan melalui dua puncline jadi jangan salahkan Neneng atuh kalo Neneng pengangguran, salahin mah orang yang makan dana uang KTP dan Maklum atuh yah orng kampung masih minta uang, kalo minta Indonesia bebas korupsi mah sulit. Apalagi kalo minta bang Radit untuk nikah, itu lebih sulit.... Bahkan itu teh mustahil, kalaupun bang Radit dapat jodoh itu teh itungannya mukjizat.

Selain itu berikut beberapa praanggapan yang muncul dalam tuturan neneng di SUCA 3 yaitu Praanggapan tentang transportasi di daerah pelosok Garut, Praanggapan keadaan wilayah di Pelosok Garut, Praanggapan mengenai hiburan di Pelosok Garut, Praanggapan mengenai kepercayaan di Pelosok Garut, dan tentang kehidupan masyarakat. Dengan demikian dapat disimpulkan bahwa praanggapan memiliki peran sangat penting dalam sebuah komunikasi, melalui sebuah praanggapan maka penutur dan petutur dapat saling memahami maksud turannya behkan pesan yang tersirat di dalamnya. Dengan demikian maka akan lebih dapat meminimalkan konflik antara penutur dan petutur. Melalui praanggapan sebuah komunikasi dapat lebih berkualitas.

Penelitian ini diharapkan dapat membantu membuka wawasan mahasiswa tentang pembahasan dalam ranah pragmatik dan dapat digunakan sebagai acuan. Jika ada penulis yang ingin melakukan penelitian lanjutan maka diharapakan untuk dapat lebih memahami praanggapan terlebih dahulu serta membahasnya dalam ranah yang lebih luas dari penelitian sebelumnya.

\section{REFERENSI}

Andryanto, S.F., Andayani, Rohmadi, M. (2014). Analisis praanggapan pada percakapan tayangan ". BASASTRA, 2, 1-16.

Leech, G. (1993). Prinsip-Prinsip Pragmatik (diterjemahkan oleh M.D.D. Oka dan Setyadi Setyapranata). Jakarta: Penerbit Universitas Indonesia.

Liang, R., \& Liu, Y. (2016). An Analysis of Presupposition Triggers in Hilary Clinton's First Campaign Speech, 6(5), 68-73. https://doi.org/10.5539/ijel.v6n5p68

Nadar, F. . (2009). Pragmatik dan Penelitian Pragmatik (Pertama). Graha Ilmu.

Purwaningrum, P. W. (2019). Praanggapan Pada Tuturan Neneng Garut: Kajian Pragmatik dalam Stand Up Comedy Academy (SUCA 3). Wanastra, 11(1), 07-14. 
Rahardi, R. K. (2005). Pragmatik Kesantunan Imperatif Bahasa Indonesia. Jakarta: Erlangga.

Retnosari, I. E. (2014). Praanggapan dan Implikatur Dalam Mr. Pecut Pada Jawa Pos. WAHANA, $63,15-20$.

Sudaryanto, S. (2015). Metode dan Aneka Teknik Analisa Bahasa: Pengantar Penelitian Wahana Kebudayaan Secara Linguistis. Yogyakarta: Sanata Dharma University Press.

Widya, W. (2015). STAND UP ZONE: IstilahIstilah dalam Stand Up Comedy.

Wijana, I. D. P. (1996). Dasar-Dasar Pragmatik. Yogyakarya: Penerbit Andi.
Yule, G. (1996). Pragmatics. Oxford: Oxford University Press.

\section{PROFIL PENULIS}

Prapti Wigati Purwaningrum was born in Kebumen 3 Mei 1984. She graduated from Sekolah Tinggi Bahasa Asing LIA Jakarta majoring in English Linguistics and post graduat program state University of Jakarta majoring applied linguistics. She has been teaching for almost 12 years in Universitas Bina Sarana Informatika. 